\title{
The effect of sulphur and nitrogen supply on the growth and nutrient content of spring wheat (Triticum aestivum $\mathbf{L}$.)
}

\author{
Evelin Kármen Juhász - Andrea Balláné Kovács \\ University of Debrecen Faculty of Agricultural and Food Sciences and Environmental Management, \\ Institute of Agricultural Chemistry and Soil Science, Debrecen \\ evelinjuhasz570@gmail.com
}

\begin{abstract}
SUMMARY
Sulphur is an essential element for plants. Decreasing sulphur deposition from the air, and the use of more concentrated phosphate fertilizers, which contain no sulphur, has led to reports of sulphur deficiencies for wheat. Sulphur deficiency significantly affects yield and also the quality of wheat. The pot experiment was set up on calcareous chernozem soil at Látókép, Hungary, test plant was spring wheat (Triticum aestivum L). Seven treatments were used where nitrogen and sulphur were supplied as soil fertilizers in increasing rates (NS1, $N S 2, N S 3)$ and in foliar fertilizer as well (NS1+fol., NS2+fol., NS3+fol.). Plant aboveground biomass production was determined in samples taken in the stages of development BBCH 29-30, 51-59, 61-69, 89. The nitrogen and sulphur content of straw and grain were measured. N/S ratios of grain and straw were calculated. The weights of grain were ranging between 8.6-16.1 g/pot. NS2 and NS2+fol. treatments produced the highest values. Foliar fertilizer had no further effect on grain. Analysing the values of the straw, it was observed that tendencies were similar to values of grain. The NS2 treatment produced the highest weight of straw and the NS3 rate already decreased that amount. The obtained results show the unfavourable effect of excessively high rate applied in NS3 treatment. The supplementary foliar fertilizer had no significant influence on the weight of straw. Both $N$ and S-uptake of plant was very intensive at the stem elongation stage, then the $N$ and S-content of plant continuously decreased in time in all treatments. The N-content of grain ranged between 2.215-2.838\%. The N-content of grain slightly increased with increasing of nitrogen doses. In the higher doses (NS2, NS3) foliar fertilization slightly increased the nitrogen content of grain, although this effect was not statistically proved. The N-content of straw varied from 0.361 to $0.605 \%$. The growing dose of soil fertilizer also considerably increased the nitrogen content of straw. Foliar fertilization further increased the nitrogen content of straw. The S-content of grain ranged between 0.174-0.266\%. The lowest fertilizer dose (NS1) significantly increased the sulphur content of grain. The further increasing fertilizer doses (NS2, NS3) did not cause additional enhance in sulphur content of grain. The foliar fertilizer also did not change the sulphur value of plant. The increasing amount of soil fertilizer and the supplementary foliar fertilizer had no effect on the sulphur content of straw. The treatments influenced the N/S ratios of grain and straw.

On the basis of experimental results it can be concluded that the examined nitrogen and sulphur containing soil fertilizer had positive effect on the growth and yield of spring wheat grown on the calcareous chernozem soil. The soil fertilizer application enhanced the grain nitrogen and sulphur content. The highest rate of fertilizer $\left(600 \mathrm{~kg} \mathrm{ha}^{-1}\right)$ proved to have decreasing effect on the yield. The sulphur and nitrogen containing foliar fertilizer did not have significant effect on the yield parameters but slightly increased the nitrogen content of plant.
\end{abstract}

Keywords: spring wheat, sulphur, nitrogen, fertilization, yield, nutrient content

\section{INTRODUCTION}

Sulphur deficiency can be a considerably increasing problem in several agricultural areas. The sulphur content of soils is constantly decreasing, which can be traced back to several reasons. Traditional fertiliser, which contains considerable amounts of S, such as single superphosphate, has been replaced progressively by fertilisers containing little or no S (Zhao and McGrath 1994, Kalocsai et al. 2003). One of the most important reasons behind the increasing $\mathrm{S}$ deficiency has been the massive decrease in the inputs of $\mathrm{S}$ from atmospheric deposition. The decreasing trend in sulphur dioxide emissions, as required by international agreements, is likely to continue well into the next decade (Zhao et al. 1999).

Nitrogen plays a central role in plant productivity because nitrogen is a major component of amino acids, proteins, nucleic acids, and chlorophyll. Nitrogen promotes rapid growth, increases leaf size and quality, hastens crop maturity, and promotes fruit and seed development (Parsons and Tinsley 1975).

Sulphur is an essential nutrient for plants. Proper sulphur delivery has a positive effect on the vegetative growth of plants, increases green weight, modifies protein content, influences the amount and proportion of protein-forming amino acids (methionine, cysteine). Increasing sulphur deficiency in plants can reduce the utilization and absorption of other nutrients, especially nitrogen (Barney and Bush 1985, Hesse et al. 2004).

The amount of $\mathrm{S}$ in spring wheat vary between 0.15-0.4\% (Reuter and Robinson 1997). The total N in spring wheat range between 1.25-3.0\% (Haynes 1986). The uptake and assimilation of sulphur and nitrogen by plants are strongly interrelated and dependent upon each other, and at adequate levels of sulphur supply the N/S ratio is around 20:1 (Barker and Pilbeam 2006). According to Györi (1998) estimated in winter wheat the $\mathrm{N} / \mathrm{S}$ ratio in average 15.

From the above mentioned reasons, it is clear that sulphur becomes limiting factor for yield formation as well as for crop quality (Eriksen et al. 2004). Therefore, it is necessary to pay attention to sulphurfertilizing and get more information about its effect on the yield and nutrient uptake of wheat. 


\section{MATERIAL AND METHODS}

The pot experiment was set up under greenhouse conditions with a calcareous chernozem soil Debrecen-Látókép with a spring wheat. Main parameters of the experimental soil are $\mathrm{pH}_{(\mathrm{CaCl} 2)}=7.2$, $\mathrm{Hu} \%=2.8, \mathrm{~K}_{\mathrm{A}}=37.5, \mathrm{AL}-\mathrm{P}_{2} \mathrm{O}_{5}=394.1 \mathrm{mg} \mathrm{kg}{ }^{-1}, \mathrm{AL}-$ $\mathrm{K}_{2} \mathrm{O}=190.8 \mathrm{mg} \mathrm{kg}{ }^{-1}, \mathrm{KH}_{2} \mathrm{PO}_{4}-\mathrm{SO}_{4}{ }^{2-}=43.6 \mathrm{mg} \mathrm{kg}^{-1}$, $\mathrm{AL}-\mathrm{Ca}=5130 \mathrm{mg} \mathrm{kg}{ }^{-1}, \mathrm{AL}-\mathrm{Mg}=403.0 \mathrm{mg} \mathrm{kg}^{-1}$. The soil was properly supplied with $\mathrm{N}$, very well supplied with $\mathrm{P}$ and poorly supplied with $\mathrm{K}$. To establish the experiment, $10 \mathrm{~kg}$ of air-dry soil was measured into pots. The moisture content of soils was maintained at $60 \%$ of the water holding capacity of the soil. Pots were weighed daily and lost water was supplemented with ion-exchanged water.

According to Ragasits (1998), the average specific nitrogen requirement for wheat is $27 \mathrm{~kg} \mathrm{t}^{-1}$, the average specific phosphorus requirement is $11 \mathrm{~kg} \mathrm{t}^{-1}$, the average specific potassium requirement is $18 \mathrm{~kg} \mathrm{t}^{-1}$, and the average specific sulphur requirement is $4.5 \mathrm{~kg} \mathrm{t}^{-1}$ (Alberta Agriculture and Forestry 2001). Considering the average yield of $4 \mathrm{tha}^{-1}$ of wheat and nutrient supply of soil, $108 \mathrm{~kg} \mathrm{ha}^{-1} \mathrm{~N}, 44 \mathrm{~kg} \mathrm{ha}^{-1} \mathrm{P}_{2} \mathrm{O}_{5}$ and 72 $\mathrm{kg} \mathrm{ha}^{-1} \mathrm{~K}_{2} \mathrm{O}$ nutrient supply was calculated.

The phosphorus and potassium (as $\mathrm{KH}_{2} \mathrm{PO}_{4}, \mathrm{KCl}$ ) was supplied uniformly in all pots. Nitrogen and sulphur were supplied as soil fertilizer in increasing doses (NS1, NS2, NS3) and were supplied in foliar fertilizer as well (NS1+fol, NS2+fol, NS3+fol). The applied soil and foliar fertilizers were commercially available fertilizers, YaraBela Sulphan and YaraVita Thiotrac 300, respectively. YaraBela Sulphan fertilizer contains $24 \% \mathrm{~N}$ and $7.2 \% \mathrm{~S}$, while the foliar fertilizer contains $15.2 \% \mathrm{~N}$ and $22.8 \% \mathrm{~S}$. The treatment plan for the experiment is shown in Table 1.

Scheme of the treatments applied

\begin{tabular}{|c|c|c|c|c|c|c|}
\hline \multirow{2}{*}{$\begin{array}{l}\text { Number of } \\
\text { treatments }\end{array}$} & \multirow{2}{*}{ Treatment label } & \multicolumn{2}{|c|}{ Fertilizer rate applied in soil } & \multirow{2}{*}{$\begin{array}{l}\text { Foliar fertilizer dose } \\
\qquad\left(1 \mathrm{ha}^{-1}\right)\end{array}$} & \multirow{2}{*}{$\begin{array}{l}\text { Nitrogen rate } \\
\left(\mathrm{kg} \mathrm{ha}^{-1}\right)\end{array}$} & \multirow{2}{*}{$\begin{array}{c}\text { Sulphur rate } \\
\left(\mathrm{kg} \mathrm{ha}^{-1}\right)\end{array}$} \\
\hline & & $\left(\mathrm{kg} \mathrm{ha}^{-1}\right)$ & (g/pot) & & & \\
\hline 1. & Control & & & - & - & - \\
\hline 2. & NS1 & 200 & 0.689 & - & 48 & 14.4 \\
\hline 3. & $\mathrm{NS} 1+$ fol. & 200 & 0.689 & 5 & 49 & 15.9 \\
\hline 4. & $\mathrm{NS} 2$ & 400 & 1.379 & - & 96 & 28.8 \\
\hline 5. & $\mathrm{NS} 2+$ fol. & 400 & 1.379 & 5 & 97 & 30.3 \\
\hline 6. & NS3 & 600 & 2.068 & - & 144 & 43.2 \\
\hline 7. & $\mathrm{NS} 3+$ fol. & 600 & 2.068 & 5 & 145 & 44.7 \\
\hline
\end{tabular}

YaraVita Thiotrac 300 foliar fertilizer was sprayed at the stage of stem elongation with the dose of $51 /$ ha.

40 grains of STANGA spring wheat were sown into all pot. In certain development stages (according to $\mathrm{BBCH}$ growth scale of wheat), at the end of the tillering, at the beginning of stem elongation (29-30), at the heading (51-59), at the flowering (61-69) stage three average plants were removed from all plots for analysis. By the end of growing season (ripening 89) 20 pieces of plants per pot lefts for harvesting. Fresh and dry weight of the plant samples per pots and height of the plants were measured. The nitrogen and sulphur content of wheat straw and wheat grain were determined by Elementar Vario EL type CNS analyser. $\mathrm{N} / \mathrm{S}$ ratios of grain and straw were calculated.

For statistical analysis of experimental results IBM SPSS Statistics 22 and Microsoft Excel 2016 programs were used. The mean values of each treatment group were subjected to comparisons analysis using the One-Way ANOVA and significance level of $\mathrm{p}<0.05$.

\section{RESULTS AND DISCUSSION}

\section{Yield indicators}

The weight of grain and straw of wheat in the stage of ripening

The dry weight of wheat grain and wheat straw per pots in stage of ripening are shown Figure 1.
According to Figure 1 the weights of grain ranged between 8.6-16.1 g/pot. All treatments increased yield, which can be statistically proved. The smallest value was control treatment and the highest value were NS2 and NS2+fol. treatments. Analysing the effect of soil fertilizer, it can be stated, that NS2 treatment produced the highest values. NS3 treatment which contained the highest amount of nutrients decreased the yield compared to value of NS2 treatment. Analysing the effect of foliar fertilizer it can be established, that foliar fertilizer had no more effect on grain yield.

The straw weights ranged between 10.9-20.7 $\mathrm{g} /$ pot. Analysing the values of the straw it was observed, that tendencies are similar, as in case of grain. The NS2 treatment produced the highest weight of straw, and compared to this the NS3 treatment already decreased that value. The results show the unfavourable effect of NS3 treatment. The supplementary foliar fertilizer had no statistically effect on the weight of straw.

\section{Average height of wheat}

Figure 2 shows the changes of the average height of wheat due to the different fertilization treatments. The values of height varied $54.2-62.7 \mathrm{~cm}$. Comparing the effects of different treatments it can be deduced, that increasing rate of soil fertilizers did not change significantly the height of plant. The foliar fertilizer also did not influence the height values of plant. 
Figure 1: The dry weight of wheat grain and wheat straw per pot in stage of ripening

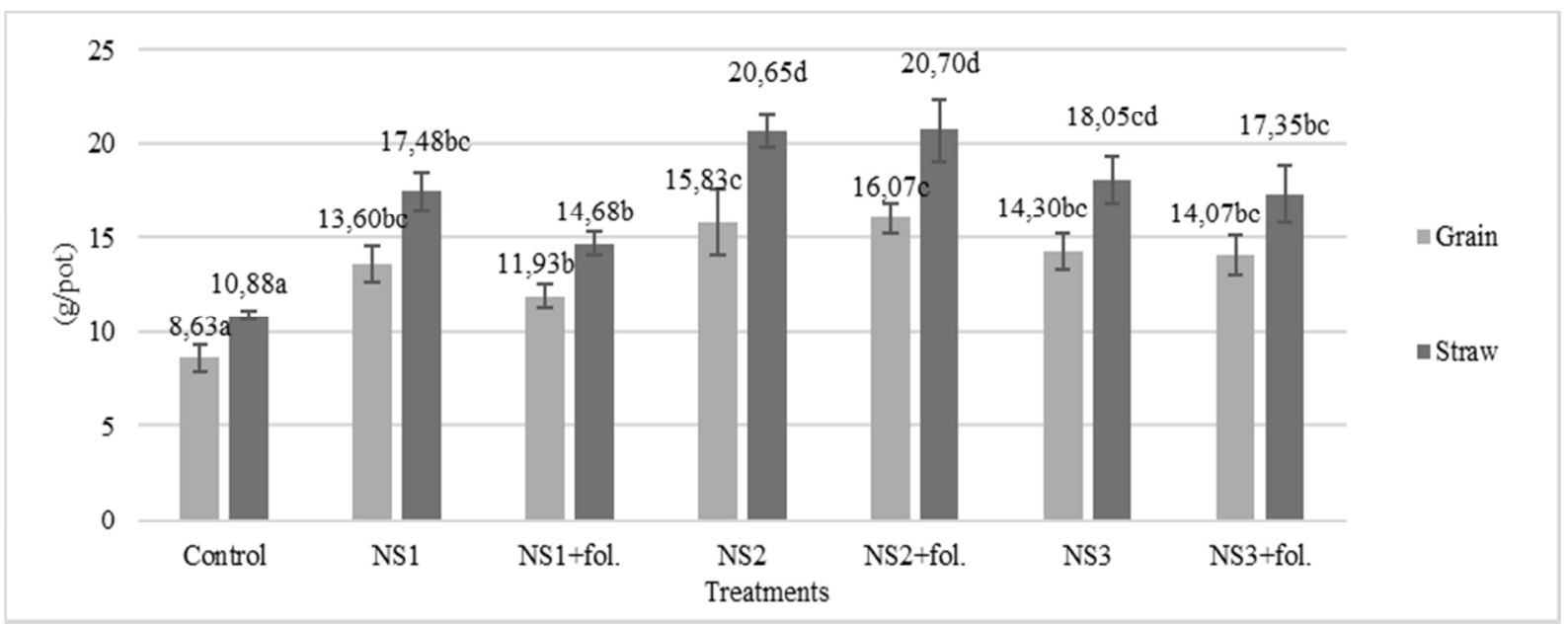

Note: data marked with the same letter is not significantly different at the significant level of $p<0.05$.

Figure 2: Effect of treatments on average plant height of wheat

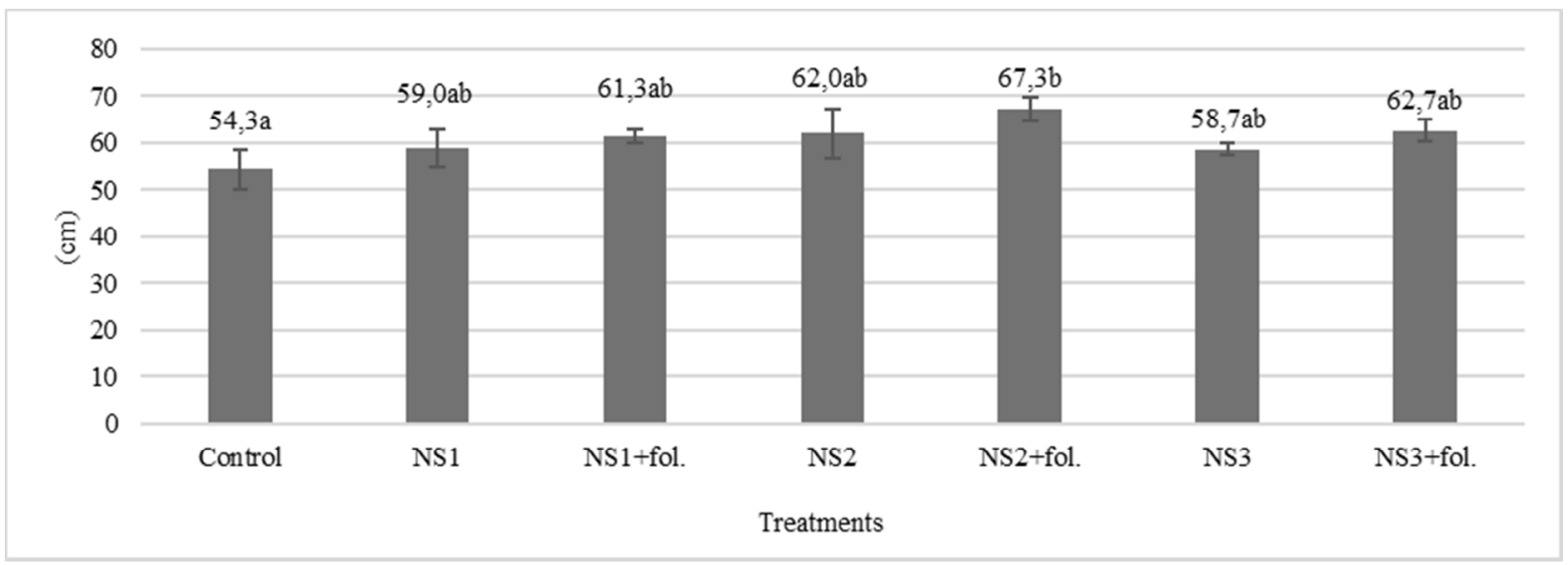

Note: data marked with the same letter is not significantly different at the significant level of $\mathrm{p}<0.05$.

\section{Quality indicators}

Changes of nitrogen and sulphur content of wheat during growing season

\section{$-N$ content of plant during the growing season}

Figure 3 shows the changes of the nitrogen content in the whole plant from the stem elongation to flowering stage.

Analysing of the changes of nitrogen content during the growing season, it can be seen, at stem elongation the $\mathrm{N}$-uptake was very intensive. Then the $\mathrm{N}$-content continuously decreased in time in all treatments. At stage of stem elongation, the N-content of the aboveground biomass varied between 4.04$5.12 \%$. The lowest value was observed in control treatment, and the highest value was measured at the highest $\mathrm{N}$-content treatment (NS3). To summarize these results, the $\mathrm{N}$-content proportionally increased with supplied $\mathrm{N}$ doses, but this can be statistically proved only by NS3 treatment. After stem elongation $\mathrm{N}$-containing foliar fertilizer was supplied.

At stage of heading the nitrogen content decreased compared to previous season. The $\mathrm{N}$-content of the aboveground biomass varied between 1.25-2.12\%. The soil fertilizer just tended to increase the $\mathrm{N}$ amount, but it can be deduced, that the statistically higher $\mathrm{N}$-content was measured by NS1+fol. and $\mathrm{NS} 3+$ fol. treatments compared to control treatment, which was due to the $\mathrm{N}$-content of foliar fertilizer.

At flowering the values slightly decreased compared to previous development stage, and these values ranged between $1.28-1.89 \%$. The increased soil fertilizer doses enhanced the $\mathrm{N}$-content, but significant higher values were measured by only $\mathrm{NS} 2+$ fol. and NS3+fol. treatments compared to control treatment.

\section{- Sulphur content of plant during the growing season}

The change of sulphur content in the different stages of development of wheat is illustrated in Figure 4. The sulphur content of plant continuously decreased in time. At the stage of stem elongation, the S-content of the aboveground biomass varied between 0.59$0.66 \%$. By the effect of growing rate of soil fertilizer the sulphur content of plant did not increased significantly.

After stem elongation S-containing foliar fertilizer was supplied. At the stage of heading the S-content of 
plant varied between $0.29-0.34 \%$. It can be seen in Figure 4 that sulphur content of plant significantly decreased compared to values of steam elongation stage. These values tended to increase with increasing of sulphur doses, but this was not statistically proved.

The sulphur content of plant did not alter from the stage of heading to the stage of flowering. At the stage of flowering, the S-content ranged between 0.29$0.36 \%$. These values tended to increase with increasing of sulphur doses to the soil but there were no further increase when we applied extra foliar fertilization.

Figure 3: Change of $\mathbf{N}$-content of the wheat in growing season

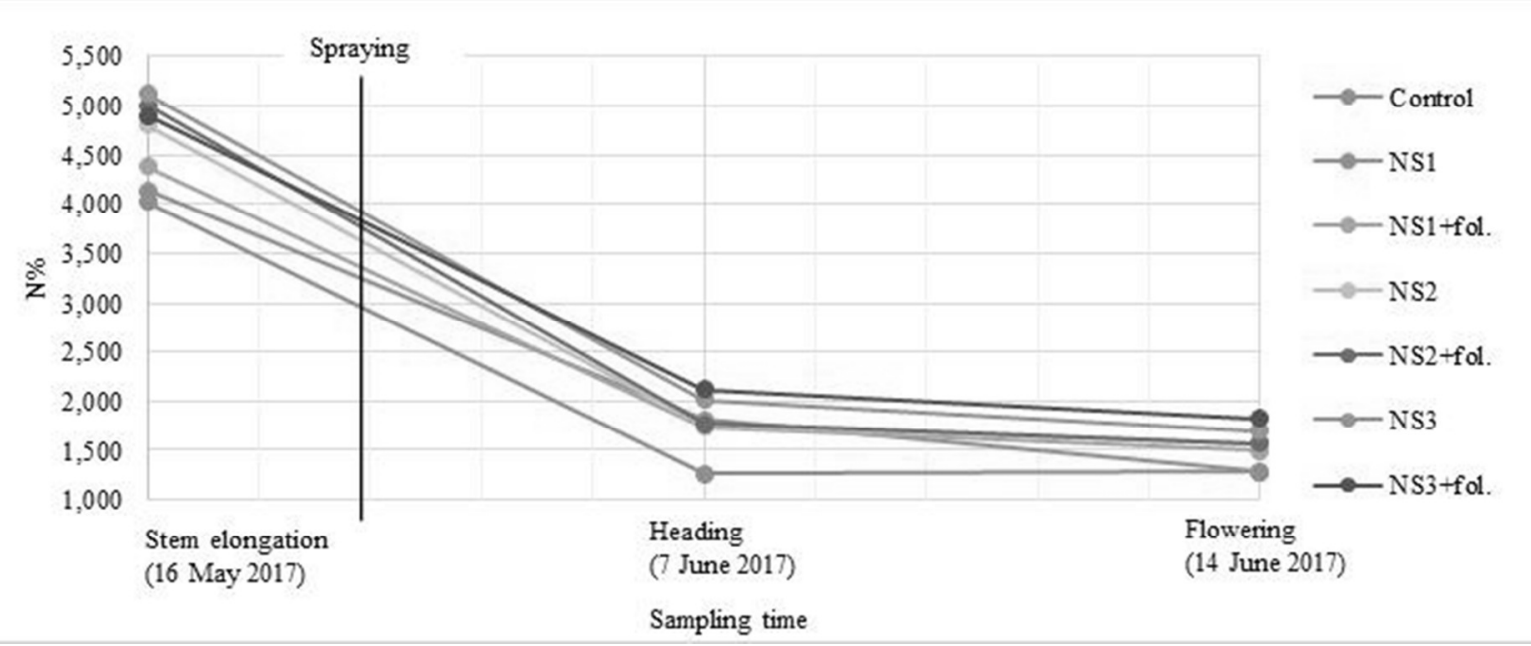

Figure 4: Change on S-content of the wheat in growing season

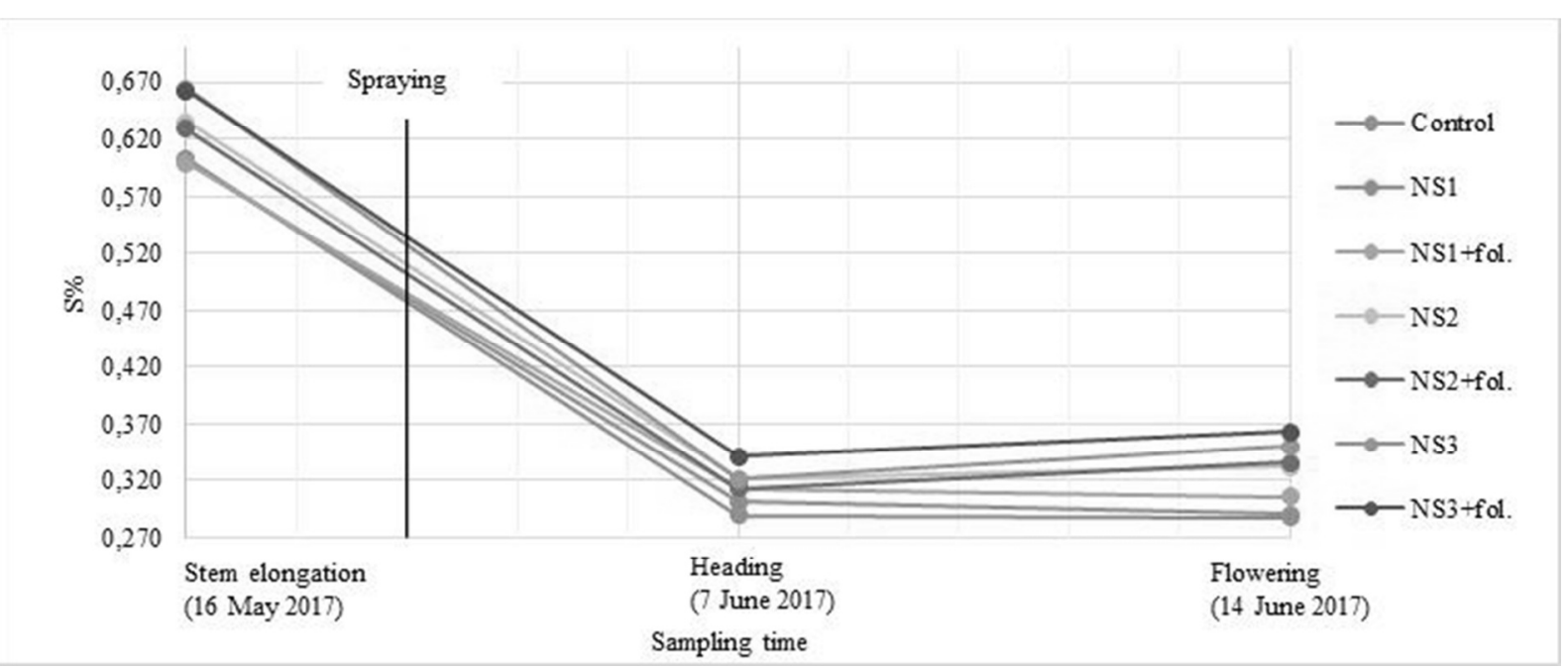

Nitrogen, sulphur content and N/S ratio of wheat in stage of ripening

Table 2 shows the change of nitrogen-, sulphurcontent and $\mathrm{N} / \mathrm{S}$ ratio of grain and straw in the ripening period due to different rate of NS containing fertilizer.

The N-content of grain ranged between 2.215$2.838 \%$. The $\mathrm{N}$-content of grain slightly increased with increasing of nitrogen doses. The highest $\mathrm{N}$-value was measured at NS3 treatment with higher $\mathrm{N}$ dose. Analyzing effect of foliar fertilizer, it can be concluded,that at NS1 treatment the nitrogen content of the grain did not increase when we applied plus foliar fertilization, but in the higher doses (NS2, NS3), supplemental foliar fertilization slightly increased the nitrogen content of wheat grain, although this effect was not statistically proved.

The S-content of grain at the stage of ripening ranged between $0.174-0.266 \%$. Győri (2005) estimated in long-term field experiments with winter wheat lower values (in average $0.15 \% \mathrm{~S}$ ). The lowest sulphur content was measured in control treatment and the lowest fertilizer dose (NS1) significantly increased the sulphur content of grain. The further increasing fertilizer doses (NS2, NS3) did not cause additional enhance in sulphur content of grain. The foliar fertilizer also did not change the sulphur value of plant. 
Nitrogen, sulphur content and N/S ratio of the wheat in stage of ripening

\begin{tabular}{|c|c|c|c|c|c|c|}
\hline \multirow{2}{*}{ Treatments } & \multicolumn{3}{|c|}{ Grain } & \multicolumn{3}{|c|}{ Straw } \\
\hline & $\mathrm{N} \%$ & $\mathrm{~S} \%$ & $\mathrm{~N} / \mathrm{S}$ & $\mathrm{N} \%$ & $\mathrm{~S} \%$ & N/S \\
\hline Control & $2.215 \mathrm{a}$ & $0.174 \mathrm{a}$ & $12.74 \mathrm{a}$ & $0.361 \mathrm{a}$ & $0.222 \mathrm{a}$ & $1.625 \mathrm{a}$ \\
\hline NS1 & $2.353 \mathrm{ab}$ & $0.237 b c$ & $9.94 \mathrm{a}$ & $0.353 \mathrm{a}$ & $0.226 a$ & $1.563 \mathrm{a}$ \\
\hline NS1+fol. & $2.251 \mathrm{a}$ & $0.226 b$ & $9.95 \mathrm{a}$ & $0.441 \mathrm{ab}$ & $0.240 \mathrm{a}$ & $1.835 \mathrm{ab}$ \\
\hline NS2 & $2.412 \mathrm{ab}$ & $0.242 b c$ & $9.97 \mathrm{a}$ & $0.427 \mathrm{ab}$ & $0.249 \mathrm{a}$ & $1.713 \mathrm{a}$ \\
\hline NS2+fol. & $2.529 \mathrm{ab}$ & $0.244 b c$ & $10.36 \mathrm{a}$ & $0.459 \mathrm{abc}$ & $0.245 \mathrm{a}$ & $1.870 \mathrm{ab}$ \\
\hline NS3 & $2.768 b$ & $0.261 b c$ & $10.60 \mathrm{a}$ & $0.542 \mathrm{bc}$ & $0.248 \mathrm{a}$ & $2.184 \mathrm{ab}$ \\
\hline NS3+fol. & $2.838 \mathrm{~b}$ & $0.266 \mathrm{c}$ & $10.68 \mathrm{a}$ & $0.605 c$ & $0.249 \mathrm{a}$ & $2.428 \mathrm{~b}$ \\
\hline
\end{tabular}

Note: data marked with the same letter in the same columns is not significantly different at the significant level of $\mathrm{p}<0.05$.

The grain N/S ratio changed between 9.94-12.74 values. According to Győri (1998) estimated in winter wheat the N/S ratio in average 15 . The most broadest $\mathrm{N} / \mathrm{S}$ ratio was found in the control treatment, and in each case, these values decreased slightly, so the sulphur content of the grain increased more, than the nitrogen content. The N/S ratio slightly increased with increasing rate of soil fertilizer, and the supplemental foliar fertilization further increased the $\mathrm{N} / \mathrm{S}$ ratio especially at the 3 . nutrient levels.

Based on the nitrogen values of straw, the nitrogen content varied from 0.361 to $0.605 \%$. These values are lower, and they are $16-21 \%$ of the nitrogen content of the grain. This can be explained by the fact that a large part of the $\mathrm{N}$ is concentrated in the grain at the stage of ripening. The growing dose of soil fertilizer also considerably increased the nitrogen content of straw. In this case, the highest N-dose (NS3) treatment resulted in the highest $\mathrm{N}$ content of straw. Foliar fertilization further increased the nitrogen content of straw, and the highest value of all treatments was measured in NS3+fol. treatment. The increasing amount of soil fertilizer and the supplementary foliar fertilizer had no effect on the sulphur content of straw.

The N/S ratio of straw was narrower than that of the grain and N/S ratio varied between 1.625 and 2.428. With increasing doses of soil fertilizer the N/S ratio of straw slightly enhanced, and verifiable higher value was only measured at $\mathrm{NS} 3+$ fol. treatment.

\section{CONCLUSION}

Nitrogen and sulphur containing fertilizers proved to have positive effect on the growth and nutrient status of wheat plant. The weight of grain and straw moreover the height of the plant increased due to „NS2+fol.” treatment, so it was proved the most favourable yield increasing treatment.

The nitrogen and sulphur content of plant decreased in time during the growing season. With increasing of soil fertilizer doses the nitrogen content of grain and straw also increased and the highest values was caused by the highest fertilizer dose (NS3). Additional foliar fertilization did not alter significantly the grain value but further increased the $\mathrm{N}$ content of straw in a statistically proved way.

The lowest fertilizer dose (NS1) significantly increased the sulphur content of grain, but the increasing fertilizer doses (NS2, NS3) did not cause additional enhance in sulphur content of grain. The foliar fertilizer did not change the sulphur value of plant.

The N/S ratio of grain was much higher and ranged between 9.94-12.74, while in straw varied between 1.625 and 2.428. Fertilization did not change the N/S ratio of grain compared to the control, but the $\mathrm{N} / \mathrm{S}$ ratio of straw significantly increased with increasing soil fertilizer doses. Supplementary foliar fertilizer further increased straw $\mathrm{N} / \mathrm{S}$ ratio and verifiable highest value was measured in the „NS3+fol.” treatment.

\section{ACKNOWLEDGEMENTS}

The work/publication is supported by the EFOP3.6.3- VEKOP-16- 2017-00008 project. The project is co-financed by the European Union and the European Social Fund.

\section{REFERENCES}

Alberta Agriculture and Forestry (2001): Wheat Nutrition and Fertilizer Requirements Sulphur. http://www1.agric.gov.ab.ca/ \$department/deptdocs.nsf/all/crop1297 (13 February 2018)

Barker, A. V.-Pilbeam, D. J. (2006): Handbook of plant nutrient. CRC Press. Taylor and Francis Group. Boca Raton. LondonNew York.

Barney, P. E. Jr.-Bush, L. P. (1985): Interaction of nitrate and sulfate reduction in tobacco-Influence of availability of nitrate and sulfate. Journal of Plant Nutrition. 8. 6: 505-515.
Eriksen, J.-Thorup-Kristensen, K.-Askegaard, M. (2004): Plant availability of catch crop sulphur following spring incorporation. J. Plant Nutr. Soil Sci. 167. 5: 609-615.

Győri Z. (1998): A termesztési tényezők hatása egyes gabonafélék és maghüvelyesek minőségére. Akadémiai doktori értekezés, Agrártudományi Egyetem. Debrecen.

Györi, Z. (2005): Sulphur content of winter wheat grain in long term field experiments. Commun. Soil Sci. Plant Anal. 36: 373-382. 
Haynes, R. J. (1986): Mineral Nitrogen in the Plant-Soil System. Academic Press Inc. New Zeland.

Hesse, H.-Nikiforova, V.-Gakière, B.-Hoefgen, R. (2004): Molecular analysis and control of cysteine biosynthesis: integration of nitrogen and sulphur metabolism. J. Exp. Bot. 55: 1283-1292.

Kalocsai R.-Schmidt R.-Földes T.-Szakál P. (2003): A mütrágyázás és elemi kén adagolás hatása a talaj kémhatására és felvehető $\mathrm{SO}_{4}{ }^{2-}$-tartalmára, Agrokémia és Talajtan. 52. 1-2: 121-132.

Parsons, J. W.-Tinsley, J. (1975) Nitrogenous substances. [In: Gieseking, J. E. (ed.) Soil Components. Vol. I.] SpringerVerlag. Berlin-New York. 263-304.
Ragasits I. (1998): Búzatermesztés. Mezőgazda Kiadó. Budapest.

Reuter, D. J.-Robinson, S. B. (1997): Plant Analysis - an Interpretation Manual. CSIRO Publishing. Australia.

Zhao, F. J.-Hawkesford, M. J.-McGrath, S. P. (1999): Sulphur assimilation and effects on yield and quality of wheat. J. Cereal Sci. 30: 1-17.

Zhao, F. J.-McGrath, S. P. (1994): Extractable sulphate and organic sulphur in soils and their availability to plants. Plant and Soil. 164. 2: $243-250$ 